Association for Information Systems AIS Electronic Library (AISeL)

ICIS 1983 Proceedings

International Conference on Information Systems

1983

\title{
Design Requirements of Office Systems
}

Giampio Bracchi

Politecnico di Mllano

Barbara Pernici

Politecnico di Mllano

Follow this and additional works at: http://aisel.aisnet.org/icis1983

\section{Recommended Citation}

Bracchi, Giampio and Pernici, Barbara, "Design Requirements of Office Systems" (1983). ICIS 1983 Proceedings. 14.

http://aisel.aisnet.org/icis1983/14

This material is brought to you by the International Conference on Information Systems (ICIS) at AIS Electronic Library (AISeL). It has been accepted for inclusion in ICIS 1983 Proceedings by an authorized administrator of AIS Electronic Library (AISeL). For more information, please contact elibrary@aisnet.org. 


\title{
Design Requirements of Office Systems*
}

\author{
Giampio Bracchi \\ Barbara Pernici \\ Dipartimento di Elettronica \\ Politecnico di Milano
}

\begin{abstract}
Automation of office work constitutes a new growing application of information systems. The original characteristics of an Office Information System (OIS) in comparison with a conventional information system imply the need for developing new design methodologies and models, which are classified and discussed in this paper.

OIS are not just document management systems (or word processing systems), 1.e., they do not consider only, or mainly, static aspects of data: they are in fact more general information systems where documents are only one of the many elements of the system. In addition, while conventional Is are often applied to support operational activities, of fice work shows many different facets, and therefore it is not reducible to a set of operational activities. Correspondingly, whlle the main phases that are commonly recognized in the design of a conventional Is (such as requirements analysis, requirements specification, logical design, optimization and implementation, system evaluation and modification) can be transferred also to OIS design, the conceptual models for requirements specifications, on which the early design phases are based, should instead be changed in order to allow the specification of particular aspects of an OIS. Such aspects include new functionalities, such as filtering of data, reminding of activities to be performed, scheduling of manual and automatic activities, and communication; some speciflc types of data are al so needed in an OIS: groups of data (documents and dossiers), unstructured and incomplete data, sophisticated handling of time, and of complex situations, distributed data, office workers roles.

Other particular aspects are related to the fact that an office system is intrisically evolutionary, and with the usage of the system: highly interactive, integrating different functions, requiring great flexibility with possible interruptions of tasks and with a high number of exceptions arising during the work.
\end{abstract}

*This paper is forthcoming in ACM Iransactions on Office Information Systems. 
In order to consider all these features in designing an OIS, the existing conceptual models that are used in conventional IS design appear usually inadequate; hence, some of them have been widely extended to be used in the new OIS environment, and many new models have been proposed. In view of the fast evolution of the technology, most of these models consider only the logical aspects of office data and activities in order to obtain independence of technological changes that affect physical implementation. Considerations on the optimization of the office logical organization are also often embodied in the model.

In general, in the literature the problem of formally specifying office elements in a model has been investigated in more depth than that of proposing a complete methodological approach to OIS design.

Hence, very few real methodologies are today in existence (for instance, OFFIS: Konsynski, Bracker, and Bracker, 1982; OAM: Sirbu, et al., 1981; Mobile-Burotique: Dumas, et a1.., 1982), and in addition most of them do not offer complete frameworks, but instead they emphasize only a subset of the OIS design phases. On the other side, many conceptual office models exist on which the requirements specification phase can be based, and some of these models consider also the subsequent step of logical optimization of the office description.

Office conceptual models can be classified, on the basis of the fundamental elements that they take into consideration, into the following main categories: databased medels, process based modelse agent based model s, and mixed models.

Generally, databased models group data into forms, which are similar to paper forms in the traditional office (E11is and Nutt, 1980, Barber, 1983, Zloof, 1981). Types of data and the operations on data (storage, retrieval, manipulation, transmission) are the basic elements of the office conceptual models. Office activities are then seen as a serles of operations on data.

Process based models are basing their analysis and description of offlce work on the idea of different activities performed concurrently by the users and the system. There are different types of models of this kind: SCOOP (Zisman, 1978), ICN (Cook, 1980), OSL (Hammer and Kunin, 1980), and Ticom-II (Balley, McAfee, and Whinston, 1983).

An office can also be modeled from the view point of the functions performed by active elements of the office environment (the agents). An agent based model (for instance, the Structural Office Model (Alello, Nardf, and Panti, 1982)) describes the office assoctating to the different 
agents a set of functionalities ( $1 . e$. , the different roles that they play in performing their tasks, the domain with in which they are authorized to act, and the set of relationships that link them to other agents, to verify system consistency).

Finally, mixed models are explicitly assuming more than one type of element as the basis for system specification, and are defining the relationships among these elements. Examples of mixed models are OFS (Tsichritzis, 1982), IML (Richter, 1981), OPAS (Lum, Choy, and Shu, 1982), Taxis extenstons as in (Barron, 1982) and (Gibbs, 1982), OFFICETALK-D (E111s and Bernal, 1982), and SOS (Bracchi and Pernici, 1983).

Most of the recent office models belong to the mixed category, since this type of model allows more complete specification of types of elements and of their interrelationships. It should also be noted that some of the models that in the early days belonged to one of the three previous mentioned categories have recently evolved to the mixed category.

A general conclusion that can be derived is that the models showing poorer technical features are instead for the moment those performing better in usage features.

Process based models show many good features, but they are considerably inadequate in the definition of data types (when this definition is considered, it is performed in a generic way). Agent based models perform well as far as activities and functions definition are concerned, but the strong dependence of all office elements on the main one (agents) implies a rather poor definition of all the other types of data.

Future developments $w 111$ more and more integrate the characteristics of the first three types of models into new mixed models; however, such global representations still require a wide research in order to be practically useful for a complete OIS design methodology.

\section{REFERENCES}

Afello, L., Nardi, D., and Panti, M. "Considerations on Office Structural Model s," Proceedings of the 84th AEI Annual Congress, $1983, \mathrm{Ca}-$ gl lart (in Italian).

Balley, A., Gerlach, J., McAfee, P., and Whinston, A. "An OIS Model for Internal Accounting Control Evalu- ation," ACM Iransactions on Office Information systems, Volume 1 , Number 1, January 1983, pp. 25-44.

Barber, G. "Supporting Organizational Problem Solving With a Work Station," ACM Iransactions on Office Information Systems, Volume 1. Number 1, January 1983, pp. 4567.

Barron, J. "Dialogue and Process 
Design for Interactive Information Systems Using Taxis," Preceedings of the ACM SIGOA Conference on Office Systems, 1982, Phfladelphia, Pennsylvania, pp. 12-20.

Bracchi, G. and Pernict B. "SOS: A Conceptual Model for Office Information Systems, " Proceedings of the ACM SIGMOD Database Week, May 1983, San Jose, California.

Cook, C "Streamlining Office Procedures - An Analysis Using the Information Control. Net Model," Preceedings of the AFIPS National Computer Conference, 1980, .pp. 555565.

Dumas P., du Roure, G., Zanetti, C., Conrath, D. and Mairet J. "MOBILEBurotique: Prospects for the Future," in Naffah, 1982, pp. 471480.

E11is, C. and Bernal M. "OFFICETALK-D: An Experimental office Information System," Proceedings of the ACM SIOGA Conference on Office Systems, 1982, Philadel phla, Pennsylvania, pp. 131-140.

Gibbs, D. "Office Information Models and the Representation of I Office Objects', "Preceedings of the ACM SIGOA Conference on Off 1 ce Systems, 1982, Philadephia, Pennsyivanta, pp. 21-26.

Konsynsk1, B., Bracker, L., and Bracker, W. "A Model for Specification of Office Communications," IEEE
Iransactions on Communications,

Vol ume COM-30, Number 1, January 1982, pp. 27-36.

Lum, V., Choy, D., and Shu, N. "OPAS: An Office Procedure Automation System," IBN Systems Jeurnal, Vol ume 21, Number 3, 1982, pp. 327350 .

Naffah, N., ed. Office Information Systems, North-Holland Publ ishing Co., Amsterdam, The Netherlands, 1982.

Richter, G. "IML - Inscribed Nets for Modeling Text Processing and Data(base) management systems," Proceedings of the Very Large Data Bases Conference, 1981, Cannes, pp. 363-375.

Sirbu, M., Scholchet, S., Kunin, J., and Hammer, M. "OAM: An Office Analysis Methodology," MIT, Office Automation Group Memo OAM-016, 1981.

Tsichritzis, D "Form Management," Communfcations of the ACM, Vol ume 25, Number 7, 1982.

Zisman M. "Use of production Systems for Modeling Asynchronous, Concurrent Processes," in Waterman and Hayes-Roth, eds., Pattern Directed Inference Systems, Academic Press, New York, 1978, pp. 53-68.

Zloof, M. "OBE/OBE: A Language for Office and Business Automation," Computer, May 1981. 